


\title{
JURNAL PENGABDIAN KESEHATAN
}

\author{
Editor In Chief \\ Eko Prasetyo, SKM, M.Kes., STIKES Cendekia Utama Kudus, Indonesia
}

\section{Editorial Board}

David Laksamana Caesar, SKM, M.Kes, STIKES Cendekia Utama Kudus, Indonesia

Sri Hartini, S.Kep, Ns, M.Kes, STIKES Cendekia Utama Kudus, Indonesia

Solikhul Huda, S.Kep, Ns, M.N.S, STIKES Cendekia Utama Kudus, Indonesia

Annik Megawati, M.Sc, Apt , STIKES Cendekia Utama Kudus, Indonesia

\section{Reviewer}

Wahyu Hidayati, Ns, M.Kep, Sp.K.M.B, Universitas Diponegoro Semarang, Indonesia dr.Mahalul Azam, M.Kes, Universitas Negeri Semarang, Indonesia

Didik Sumanto, SKM, M.Kes(Epid), Universitas Muhammadiyah Semarang, Indonesia

\section{English Language Editor}

Arina Hafadhotul Husna, S.Pd, M.Pd., STIKES Cendekia Utama Kudus, Indonesia

\section{IT Support}

Susilo Restu Wahyuno, S.Kom., STIKES Cendekia Utama Kudus, Indonesia

\section{Penerbit}

Lembaga Penelitian dan Pengabdian Masyarakat (LPPM)

STIKES Cendekia Utama Kudus

\author{
Alamat \\ Jalan Lingkar Raya Kudus - Pati KM.5 Jepang Mejobo Kudus 59381 \\ Telp. (0291) 4248655, 4248656 Fax. (0291) 4248651 \\ Website : http://jpk.jurnal.stikescendekiautamakudus.ac.id/ \\ Email : jurnal@stikescendekiautamakudus.ac.id
}

Jurnal Pengabdian Kesehatan merupakan jurnal ilmiah hasil-hasil pengabdian masyarakat didalam pemberdayaan di bidang Kesehatan yang diterbitkan oleh Lembaga Penelitian dan Pengabdian Masyarakat (LPPM) STIKES Cendekia Utama Kudus secara berkala 2 (dua) kali dalam satu tahun. 


\section{DAFTAR ISI}

Halaman Judul

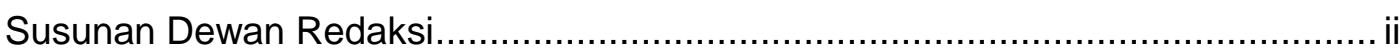

Kata Pengantar .............................................................................................

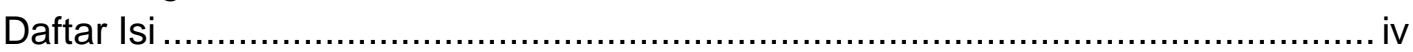

Peningkatan Produktifitas Kerja dengan Penerapan Prinsip-Prinsip K3 di Lingkungan Kerja

Eko Prasetyo, David Laksamana Caesar, Arina Hafadhotul Husna............. 1

Pengembangan Manisan Lidah Buaya sebagai Obat Pencahar Alami

Yulia Pratiwi, Ina Ristian, Ricka Islamiyati.

Edukasi Kesehatan Farmasi Penyakit Rematik di Desa Nganguk Kota Kudus

Annis Rahmawaty, Endra Pujiastuti, Lilis Sugiarti

Pencegahan HIV AIDS-Has Save Kids Jaman Now pada Siswa SMK AI-Islam Kudus

Rohmatun Nafi'ah, Sholihul Huda

Penerapan Pemberantasan Sarang Nyamuk Demam Berdarah Dengue (PSN 3 M Plus-DBD) pada Anak Usia Sekolah dengan Pendekatan Komunikasi Perubahan Perilaku di SDN 4 Kecamatan Kalinyamatan Jepara

Galia Wardha Alvita, Sholihul Huda, Ilham Setyo Budi.

Peningkatan Kualitas Kesehatan Anak dengan Penerapan Cara Mencuci Tangan yang Benar dan Pengenalan tentang Obat Kepada Anak Usia Dini Annik Megawati, Ema Dwi Hastuti, Dessy Erliani Mugita Sari

Terapi Bermain pada Anak Prasekolah untuk Menurunkan Tingkat Kecemasan Saat Hospitalisasi

Sri Hartini, Biyanti Dwi Winarsih, Erna Sulistyawati.

\section{Lampiran}

Pedoman Penulisan Naskah JPK 


\title{
PENCEGAHAN HIV AIDS-Has Save Kids Jaman Now PADA SISWA SMK AL-ISLAM KUDUS
}

\author{
Rohmatun Nafi'ah ${ }^{1}$, Sholihul Huda ${ }^{2}$ \\ 1,2 STIKES Cendekia Utama Kudus \\ nafie_qudsy@yahoo.com
}

\begin{abstract}
ABSTRAK
AIDS merupakan suatu penyakit yang belum ada obatnya dan belum ada vaksin yang bisa mencegah serangan virus HIV, sehingga penyakit ini merupakan salah satu penyakit yang sangat berbahaya bagi kehidupan manusia baik sekarang maupun waktu yang akan datang. Permasalahannya remaja saat ini begitu minim pengetahuan tentang HIV AIDS, sehingga perlu adanya edukasi pencegahan HIV AIDS dengan tema "Has Save Kids Jaman Now". Tujuan dari program pengabdian masyarakat ini antara lain: Sebagai tolak ukur kepedulian siswa dan siswi khususnya generasi muda terhadap AIDS, mencegah meluasnya seks bebas dikalangan pelajar, menggugah kesadaran pelajar terhadap bahaya AIDS, serta menciptakan generasi muda yang mampu berkarya, dan mengharumkan nama bangsa yang sehat tanpa AIDS. Program pengabdian masyarakat ini telah dilakukan melalui: penyuluhan tentang pencegahan HIV AIDS-Has Save Kids Jaman Now. Hasil dari kegiatan ini terlihat dengan adanya penyuluhan tersebut siswa SMK Al-Islam Kudus lebih memahami HIV AIDS khususnya terhadap pencegahannya, sehingga siswa akan memberikan sikap positif terhadap pencegahan HIV AIDS.
\end{abstract}

Kata Kunci : Pencegahan ; HIV ; AIDS

\section{ABSTRACT}

AIDS is a disease that has no cure and there is no vaccine that can prevent the HIV virus, so this disease is one of the diseases that are very dangerous for human life both now and the time to come. The problem of today's teenagers so minimal knowledge about HIV AIDS, so the need for HIV AIDS prevention education with the theme "Has Save Kids Now". The objectives of this community service program are as a benchmark of students' concern and especially young generation of students towards AIDS, to prevent the spread of free sex among students, to awaken the awareness of the students to the dangers of AIDS, and to create young people who are able to work, and to nurture the name of a healthy nation without AIDS. This community service program has been conducted through: HIV AIDS prevention counseling-Has Save Kids Now. The result of this activity is seen by the counseling students of SMK Al-Islam Kudus understand more about HIV AIDS especially to its prevention so that students will give positive attitude toward HIV AIDS prevention.

Keywords: Prevention; HIV; AIDS 


\section{PENDAHULUAN}

AIDS (Acquired Immune Deficiency Syndrom) adalah kumpulan gejala atau penyakit yang disebabkan oleh menurunnya kekebalan tubuh akibat infeksi oleh HIV (human immunodeficiency virus). Penyakit ini ditandai dengan gejala menurunnya sistem kekebalan tubuh dan biasanya berakhir dengan kematian. [2]

HIV/AIDS tidak bisa dipandang sebelah mata lagi dilihat dari jumlah penderitanya yang tidak sedikit. Karena hal tersebut pemerintah Indonesia menetapkan Peraturan Mentri Kesehatan Republik Indonesia Nomor 21 Tahun 2013 tentang penanggulangan HIVdan AIDS. Selain itu masyarakat pun turut andil dalam menanggulangi HIV dan AIDS di Indonesia, salah satunya dengan forum WPA (Warga Peduli AIDS) yang diharapakan bisa menjadi media untuk memberikan informasi mengenai HIV/AIDS sehingga stigma dan diskriminasi akan berkrang pada ODHA. Selain itu dengan forum WPA juga diharapkan orang yang beresiko tinggi mau memeriksakan diri di layanan kesehatan. Dan harapan lain dari forum WPA adalah orang yang terinfeksi HIV/AIDS mau membuka diri sehingga penularan bisa dikendalikan dan mendapatkan terapi. [3]

Remaja saat ini begitu minim pengetahuan tentang seksualitas, sehingga banyak dari mereka yang sering melakukan coba-coba untuk melakukan hubungan seksualitas diluar nikah. Bahkan hubungan seksualitas dilakukan tidak hanya dengan satu pasangan namun bergantiganti pasangan, perilaku yang demikian dapat menyebabkan terkena virus HIV. Berdasarkan latar belakang tersebut, sehingga perlu adaya edukasi dikalangan pelajar SMA tentang HIV AIDS dan bagaimana upaya untuk melakukan pencegahan dari HIV AIDS dengan tema "Has Save Kids Jaman Now" pada siswa SMK AL-Islam Kudus. Penyuluhan dapat mempengaruhi sikap seseorang dalam berperilaku sehat.[1] Penyuluhan kesehatan tentang HIV/AIDS dapat berpengaruh terhadap sikap remaja tentang pencegahan HIV/AIDS.[4] 


\section{METODE}

Program pengabdian masyarakat ini dilakukan melalui penyuluhan tentang pencegahan HIV AIDS-Has Save Kids Jaman Now. Pengabdian Masyarakat dimulai dengan kegiatan survei awal yang dilakukan pada beberapa siswa/i SMK AL-Islam Kudus, ada beberapa masalah yang teridentifikasi yaitu pemahaman tentang beberapa aspek HIV/AIDS yang masih belum tepat, serta meningkatnya perilaku berisiko terkait HIV/AIDS. Adanya masalah pengetahuan siswa/i yang masih rendah dan keliru tersebut disebabkan karena selama ini mereka hanya mendapatkan informasi dari teman sebaya atau dari orang tua. Selain itu, belum pernah diadakan penyuluhan tentang HIV/AIDS di sekolah ataupun di lingkungan tempat tinggal mereka.

Untuk itu kegiatan penyuluhan dengan metode ceramah dan diskusi dilakukan dengan tujuan memberikan pengetahuan yang benar tentang pencegahan dan cara penularan HIV/AIDS sedini mungkin pada remaja yaitu siswa/i SMK Al-Islam Kudus. Kegiatan ini diharapkan dapat mencegah munculnya perilaku berisiko terkait HIV/AIDS sehingga dapat mengurangi penularan HIV/AIDS dan kasus baru di masyarakat terutama di kalangan remaja. Selain itu diharapkan siswa/i SMK AI-Islam Kudus nantinya bersedia menjadi duta atau menyebarkan informasi ini kepada temanteman sebaya, sehingga dapat menekan penyebaran dan kasus HIV/AIDS dikalangan remaja.

\section{HASIL DAN PEMBAHASAN}

\section{Penyuluhan tentang Pencegahan HIV AIDS-Has Save Kids Jaman Now}

Sebelum penyuluhan, telah dilakukan koordinasi dengan pihakpihak terkait yaitu dengan pihak sekolah melalui Kepala Sekolah untuk menetapkan jumlah sasaran, tempat dan waktu kegiatan. Penyuluhan Pencegahan HIV AIDS-Has Save Kids Jaman Now dilaksanakan di SMK Al-Islam Kudus. Kegiatan penyuluhan dilaksanakan pada hari Rabu 
tanggal 13 Desember 2017 pukul 09.30-12.30 sebanyak 90 orang pelajar kelas XI dan XII. Sebelum ceramah dimulai, para peserta diberikan pertanyaan tentang pencegahan dan penularan HIV/AIDS dengan tujuan untuk mengetahui tingkat pengetahuan awal peserta.

Selanjutnya, ceramah diberikan selama 60 menit dengan menggunakan media LCD dan slide power point.

Materi ceramah yang diberikan meliputi:

1. Pengertian HIV/AIDS

2. Cara penularan HIV/AIDS, termasuk perilaku berisiko tertular HIV/AIDS

3. Tanda dan Gejala HIV/AIDS

4. Cara Pencegahan HIV/AIDS

Para peserta penyuluhan terlihat antusias dalam mengikuti penyuluhan. Hal ini terlihat dari sejumlah siswa yang mengajukan pertanyaan tentang HIV dan AIDS. Untuk meningkatkan minat dan partisipasi peserta, siswa yang mengajukan pertanyaan diberikan hadiah kecil. Selain itu, untuk menghindari kebosanan peserta, pemateri memberikan pertanyaan yang berkaitan dengan materi di tengah-tengah sesi ceramah dan yang menjawab benar mendapatkan door prize.

Sebagai evaluasi akhir, yaitu untuk mengetahui peningkatan pengetahuan peserta, di akhir acara diberikan pertanyaan tentang materi yang telah disampaikan dalam bentuk pertanyaan yang sama dengan pertanyaan awal. Peserta sudah ada peningkatan pemahaman terhadap HIV AIDS dan pencegahannya.

Tanggapan pihak sekolah SMK Al-Islam Kudus tentang kegiatan ini sangat positif. Kepala sekolah dan staf mengharapkan kegiatan penyuluhan seperti ini bisa dilaksanakan secara kontinyu di sekolah mereka terutama tentang masalah kesehatan bagi para remaja. Para siswa pun merasakan mendapatkan informasi yang baru tentang pencegahan dan penularan HIV/AIDS. Informasi yang didapat sangat bermanfaat bagi mereka sehingga dapat menghindarkan mereka dari berperilaku berisiko tertular HIV/AIDS. 
Penilaian keberhasilan terhadap kegiatan ini dapat dilihat dari proses penyuluhan yang berlangsung sangat baik. Seluruh siswa memperhatikan dengan baik materi yang disampaikan. Guru BK membantu untuk mengawasi siswa/i sehingga proses penyuluhan berjalan lancar. Selain itu keberhasilan penyuluhan ini dapat dilihat dari peningkatan pengetahuan siswa/l tentang pencegahan dan penularan HIV/AIDS yaitu membandingkan jawaban-jawaban dari pertanyaan sebelum dilakukan penyuluhan dan setelah dilakukan penyuluhan.
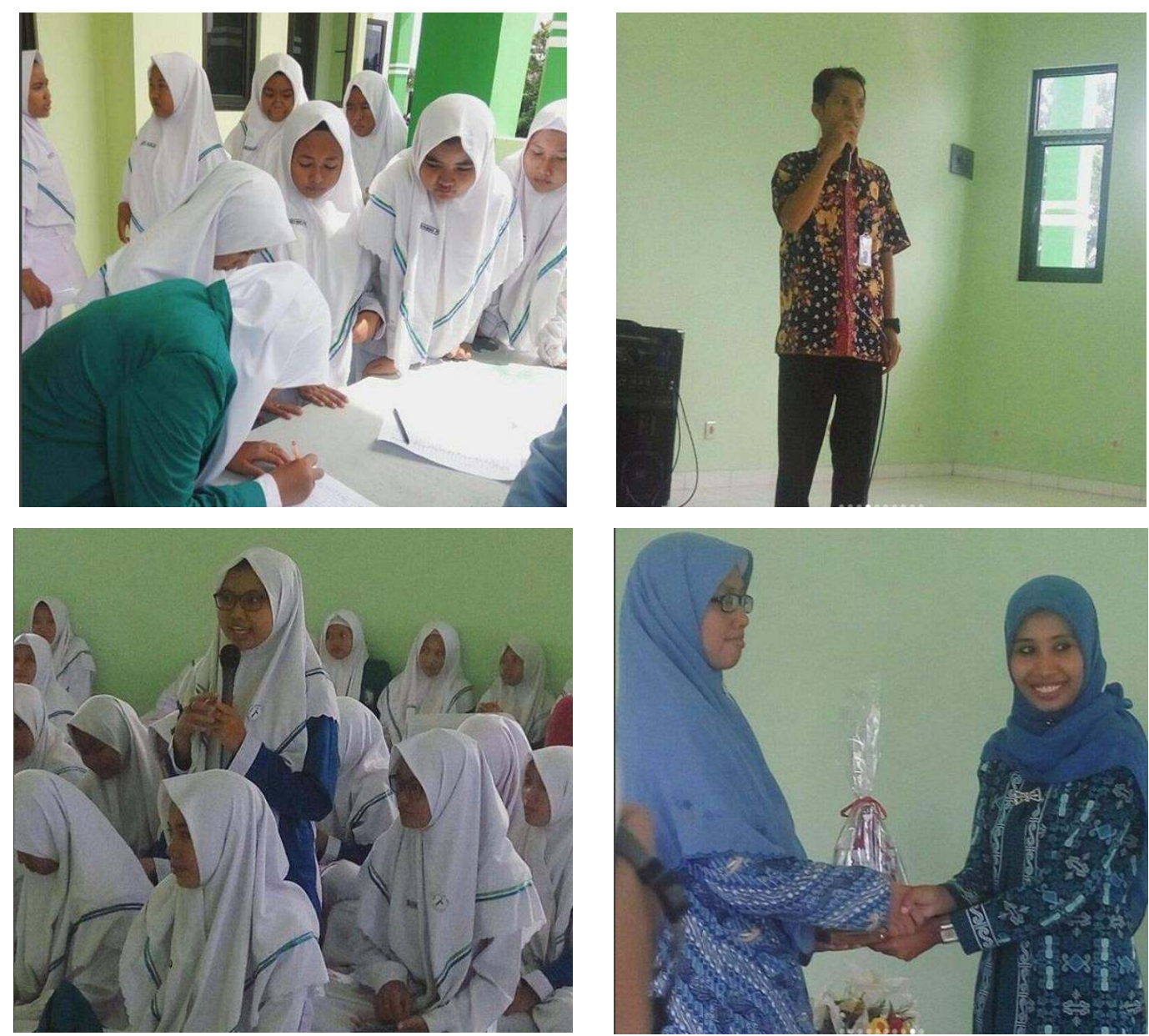

Gambar 1.

Hasil Kegiatan Penyuluhan Pencegahan HIV/AIDS 


\section{SIMPULAN DAN SARAN}

\section{Simpulan}

Berdasarkan hasil dan luaran yang telah dicapai, maka dapat ditarik kesimpulan bahwa dengan adanya penyuluhan pencegahan HIV AIDSHas Save Kids Jaman Now, secara umum pelaksanaan penyuluhan yang direncanakan telah berlangsung dengan baik. Selama persiapan, koordinasi dengan pihak sekolah berjalan dengan baik. Selama penyuluhan,dapat diketahui bahwa telah terjadi peningkatan pengetahuan siswa/i SMK Al-Islam Kudus tentang pencegahan dan cara penularan HIV/AIDS.

\section{Saran}

Kegiatan pengabdian kepada masyarakat seperti penyuluhan kesehatan tentang pencegahan dan penularan HIV dan AIDS perlu dilakukan secara kontinyu, karena melihat masih rendahnya tingkat pengetahuan remaja tentang pencegahan dan penularan HIV dan AIDS.

Bagi siswa SMK Al-Islam Kudus diharapkan lebih aktif dalam menggali informasi yang benar mengenai kesehatan reproduksi khususnya tentang HIV/AIDS. Sumber informasi langsung bisa diperoleh saat pelajaran agama maupun bimbingan konseling,. Sumber informasi tak langsung dapat diperoleh dari buku bacaan, majalah, leaflet. Adanya informasi yang jelas dan benar akan meningkatkan pengetahuan yang baik pada remaja tentang HIV/AIDS sehingga kasus HIV/AIDS di kalangan remaja dapat diminimalisasi.

Bagi Kepala Sekolah SMK Al-Islam Kudus diharapkan dapat memberikan fasilitas pendidikan kesehatan reproduksi salah satunya mengenai HIV/AIDS melalui bimbingan konseling yang telah ada. Disamping itu pihak sekolah diharapkan bekerja sama dengan petugas kesehatan dilingkungan sekitar, seperti puskesmas, atau dinas-dinas kesehatan yang mencakup wilayah tersebut untuk memberikan 
pendidikan kesehatan dan meningkatkan pengetahuan serta mencegah dari hal-hal yang tidak diinginkan.

\section{UCAPAN TERIMA KASIH}

Kegiatan ini dapat terlaksana dengan baik berkat dukungan berbagai pihak. Pada kesempatan ini kami mengucapkan terimakasih kepada Ketua LPPM STIKES Cendekia Utama Kudus, HIMFAKIA, Kepala Sekolah SMK Al-Islam Kudus beserta staf, siswa/i SMK Al-Islam Kudus serta kepada semua pihak yang telah mendukung penyelenggaraan pengabdian kepada masyarakat ini.

\section{DAFTAR PUSTAKA}

1. Ayuningsih, N. 2015.Pengaruh Penyuluhan tentang HIV/AIDS terhadap Pengetahuan dan Sikap Siswa di SMA Negeri 1 Manado. (Skripsi Ilmiah). Manado: Universitas Sam Ratulangi Manado.

2. Burns, A., Lovich, R., Maxwell, J., Shapiro, K. (2009). Perempuan dan Aids. Yogyakarta: KDT

3. Ditjen PP \& PL Kemenkes RI. 2014. Statistik Kasus HIV/AIDS di Indonesia. Ditjen PP \& PL Kemenkes RI. Jakarta.

4. Notoadmodjo, S. 2007. Promosi Kesehatan dan Perilaku Kesehatan. Jakarta Rineka Cipta. 


\section{PEDOMAN PENULISAN NASKAH JPK}

Jurnal Pengabdian Kesehatan (JPK) STIKES Cendekia Utama Kudus menerima naskah hasil-hasil pengabdian masyarakat di dalam pemberdayaan di bidang kesehatan.

Naskah adalah karya asli penulis, bukan plagiat, saduran atau terjemahan karya penulis lain.

Naskah khusus ditujukan kepada Jurnal Pengabdian Kesehatan (JPK) STIKES Cendekia Utama Kudus, belum pernah dipublikasikan di media lain. Naskah yang dikirim harus disertai surat persetujuan publikasi dan surat pengantar yang ditandatangani penulis.

\section{Komponen naskah:}

Judul, ditulis maksimal 150 karakter, huruf Book Antiqua, ukuran 13, spasi 1

$\square \quad$ Identitas penulis, ditulis setelah judul. Terdiri atas nama (tanpa gelar), alamat tempat kerja, nomor telepon/hp dan alamat email.

Abstrak dalam bahasa Indonesia dan bahasa Inggris, maksimal 200 kata, disusun dalam satu alinea, berisi masalah, tujuan, metode pelaksanaan, hasil dan 3-5 kata kunci. Untuk naskah dalam bahasa Inggris, tidak perlu disertai abstrak dalam bahasa Indonesia.

$\square$ Pendahuluan, tanpa subjudul, berisi latar belakang, sedikit tinjauan pustaka dan tujuan program pengabdian.

$\square$ Metode, dijelaskan secara rinci variasi kegiatan melalui tahapan didalam pelaksanan pengabdian masyarakat di bidang kesehatan

$\square$ Hasil dan Pembahasan, mengurai secara tepat dan argumentatif hasil program pengabdian, kaitan hasil dengan teori yang sesuai dan sistematis.

Tabel atau gambar. Tabel, diberi nomor sesuai urutan penyebutan dalam teks, ditulis 1 (satu) spasi, ukuran 11. Judul singkat, padat dan jelas, terletak di atas tabel. Gambar, diberi nomor sesuai urutan penyebutan dalam teks. Judul singkat, padat dan jelas, terletak di bawah gambar. 
$\neg$ Simpulan dan Saran. Simpulan menjawab masalah program pengabdian dengan pernyataan tegas. Saran logis, tepat guna dan tidak mengada-ada, dan ada keterkaitan dengan keberlanjutan program pengabdian

$\square \quad$ Rujukan/ referensi ditulis sesuai aturan Vancouver, urut sesuai dengan pemunculan dalam keseluruhan teks, maksimal 25 rujukan dan 75 persen merupakan publikasi dalam 10 tahun terakhir.

Naskah sebanyak 15-25 halaman kuarto, batas atas-bawah-tepi kiri-tepi kanan $(\mathrm{cm}): 4-3-4-3$, spasi 1,5, jenis huruf: arial, ukuran 12, format microsoft word, dalam bentuk softfile dan 3 (tiga) eksemplar dalam bentuk print out.

Naskah dikirim ke alamat : Redaksi Jurnal Pengabdian Kesehatan (JPK) STIKES Cendekia Utama Kudus, Jl. Lingkar Raya Km.05 Jepang Mejobo Kudus 59381.

\section{Kontak langsung dapat melalui:}

Eko Prasetyo $: 081575435102$

David Laksamana Caesar : :085727448958

Sholihul Huda : 081326404743

Naskah juga dapat dikirim melalui email :

Ippm.stikescendekiautama@yahoo.com 


\section{CONTOH PENULISAN DAFTAR PUSTAKA}

\section{Artikel Jurnal Penulis Individu.}

Sloan NL, Winikoff B, Fikree FF. An ecologic analysis of maternal mortality ratios. Stud Fam Plann 2001;32:352-355.

\section{Artikel Jurnal Penulis Organisasi}

Diabetes Prevention Program Research Group. Hypertension, insulin, and proinsulin in participants with impaired glucose tolerance. Hypertension.2002;40(5):679-86

\section{Artikel Jurnal di Internet}

Goodyear-Smith F and Arroll B, Contraception before and after termination of pregnancy: can we do it better? New Zealand Medical Journal, 2003, Vol. 116, No. 1186, <http://www.nzma.org.nz/journal/116-1186/683/content. pdf>, accessed Aug. 7, 2007.

\section{Buku Dengan Nama Editor sebagai penulisnya}

Lewis G, ed. Why mothers die 2000-2002: the confidential enquiries into maternal deaths in the United Kingdom. London: RCOG Press; 2004.

\section{Buku yang Ditulis Individu}

Loudon I. Death in childbirth. An international study of maternal care and maternal mortality 1800-1950.London: Oxford University Press, 1992.

\section{Buku yang Ditulis Organisasi}

Council of Europe, Recent Demographi Developments in Europe 2004, Strasbourg, France: Council of Europe Publishing, 2005.

\section{Artikel dari Buletin}

Ali MM, Cleland $\mathrm{J}$ and Shah $\mathrm{IH}$, Condom use within marriage: a neglected HIV intervention, Bulletin of the World Health Organization, 2004, 82(3):180186.

\section{Paper yang Dipresentasikan dalam Pertemuan IImiah/Konferensi} Kaufman J, Erli Z and Zhenming X, Quality of care in China: from pilot project to national program, paper presented at the IUSSP XXV International Population Conference, Tours, France, July 18-23, 2005. 


\section{Bab dalam Buku}

Singh S, Henshaw SK and Berentsen K, Abortion: a worldwide overview, in: Basu AM, ed., The Sociocultural and Political Aspects of Abortion,Westport, CT, USA: Praeger Publishers, 2003, pp. 15-47.

\section{Data dari Internet}

U.S. Bureau of the Census, International Data Base, Country summary: China, 2007, <http://www.census.gov/ipc/ www/idb/country/chportal.html>, accessed Aug. 12, 2007.

\section{Disertasi}

Lamsudin R. Algoritma Stroke Gadjah Mada (Disertasi). Yogyakarta: Universitas Gadjah Mada. 1997

\section{Makalah dalam Surat Kabar}

Banzai VK, Beto JA. Treatment of Lupus Nephritis. The Jakarta Post 1989; Dec 8; Sect A.5(col 3)

\section{Kamus}

Ectasia. Dorland's Illustrated Medical Dictionary.27th ed. Philadelphia: Saunders, 1988;527 